\title{
KARŞILIKLI GÜVEN ILKESİ İLE TEMEL HAKLARIN KORUNMASI ARASINDAKİ MAKUL DENGE ARAYIŞI: AVRUPA TUTUKLAMA MÜZEKKERESİ ÖRNE $\breve{I}$
}

\section{İlke GÖÇMEN*}

\section{$\ddot{O} z$}

Karşıllılı güven ilkesi; özgürlük, güvenlik ve adalet alanının köşe taşı olarak kabul edilmekte olan karşıllılı tanıma ilkesine temel oluşturur. Karşıllklı güven ilkesi, esasen, Avrupa Birliği (AB) üyesi devletlerin, diğer üye devletlerin özellikle $A B$ hukukunun tanıdı ̆̆ temel haklara uyduğunu addetmelerini gerektirir. $O$ halde, karşıllklı güven ilkesi aslında bir karinedir. Peki, bu ilke mutlak bir karine midir (i), yoksa çürütülebilir bir karine midir (ii)? Avrupa Birliği Adalet Divanı içtihat hukuku, tarihsel gelişim sürecine bakıldığında birinci durumdan ikinci duruma doğru evirilmiş gözükmektedir. Bu çalışmanın amacı, karşılıklı tanıma ve dolayısıyla güven ilkesinin ilk kullanımı olan Avrupa Tutuklama Müzekkeresi örneği üzerinden, karşılıklı güven ilkesi ile ilgili bu dönüşümü, nedenleri ve sonuçları ile birlikte ortaya koymak, böylece bu dönüşümün tamamlanıp tamamlanmadı̆̆ı başta olmak üzere, geleceğe dair de bazı çıkarımlar yapmaktır.

Anahtar kelimeler: Karşılıklı güven ilkesi, temel hakların korunması, özgürlük, güvenlik ve adalet alani, Avrupa Tutuklama Müzekkeresi, Avrupa Birliği Adalet Divanı içtihat hukuku.

\section{SEARCH FOR A REASONABLE BALANCE BETWEEN PRINCIPLE OF MUTUAL TRUST AND PROTECTION OF FUNDAMENTAL RIGHTS: EUROPEAN ARREST WARRANT AS AN EXAMPLE}

\section{Abstract}

Principle of mutual trust forms the basis of principle of mutual recognition which has been recognised as the cornerstone of the area of freedom, security

* Doç. Dr., Ankara Üniversitesi Hukuk Fakültesi Avrupa Birliği Hukuku Anabilim Dalı, e-posta: igocmen@ankara.edu.tr 
and justice. Essentially, the principle of mutual trust requires that any European Union (EU) Member State should assume that other Member States observe especially the fundamental rights recognized by EU law. Hence, the principle of mutual trust is indeed a presumption. Then, does this principle establish an absolute presumption (i), or a rebuttable presumption (ii)? Considering the historical development process, the case-law of the Court of Justice of the European Union seem to have evolved from the first condition to the second condition. Via the example of European Arrest Warrant which is the first use of principle of mutual recognition and hence mutual trust, this Article aims to present this evolution regarding the principle of mutual trust in conjunction with its reasons and consequences, and to draw some conclusions regarding the future, particularly about whether this evolution has been over or not.

Keywords: Principle of mutual trust, protection of fundamental rights, area of freedom, security and justice, European Arrest Warrant, case-law of the Court of Justice of the European Union.

\section{Giriş}

Avrupa Birliği (AB), tarihsel kökleri 1970’li yıllara kadar götürülebilen “iç sınırların olmadığı bir özgürlük, güvenlik ve adalet alanı" kurmayı 2009'dan beri açık bir hedef olarak benimsemektedir (Lizbon Antlaşması ile değişik Avrupa Birliği Antlaşması, 2007, md. 3(2)). Peki, bir hedef olarak özgürlük, güvenlik ve adalet alanına nasıl erişilecektir? İşte karşılıklı tanıma ilkesi, bu alana erişmek için seçilen yöntemlerden birisi ve görece öne çıkanı olmuştur. $\mathrm{Bu}$ ilke, öz olarak, $\mathrm{AB}$ çapında uyumlaştırmanın yerine, "bir üye devletin münferit ulusal standardının, kararının veya emrinin diğer üye devletler tarafından [kural olarak] tanınmasını" ve dolayısıyla "uygulanmasını ve/veya icra edilmesini gerektirir" (Mitsilegas, 2009: 119). Böyle bir ilke, kuşkusuz, ancak üye devletler arasında birbirlerine güven olduğu varsayımı altında işleyebilir. İşte karşılıklı tanıma ilkesine temel oluşturan karşılıklı güven ilkesine göre "her bir üye devletin kendi ulusal hukuk sistemi [AB] çapında tanınan ile denk ve etkili temel hak koruması sağlamaya elverişlidir" (Jeremy F. v Premier ministre, Case C-168/13 PPU, 2013, para. 50).

Öyleyse karşılıklı güven ilkesi aslında bir karinedir, peki, mutlak bir karine midir, yoksa çürütülebilir bir karine midir? ABAD içtihat hukuku, tarihsel gelişim sürecine bakıldığında, karşılıklı güven ilkesinin mutlak bir karineden çürütülebilir bir karineye dönüşümüne işaret etmektedir. İşte bu çalışma, bu dönüşümü, nedenleri ve sonuçları ile birlikte ortaya koymayı, böylece bu dönüşümün tamamlanıp tamamlanmadığı başta olmak üzere, geleceğe dair de birtakım çıkarımlar yapmayı amaçlamaktadır. Dahası, Avrupa Tutuklama 
Müzekkeresi'ne (ATM) ilişkin 2002/584 sayılı Çerçeve Karar ([2009] OJ L 81/24 ile değişik [2002] OJ L 190/1), konuyu belirli bir örnek üzerinden ilerletmenin konuyu daha anlaşılır kılacağ 1 düşüncesiyle örnek olarak seçilmiştir. Bu seçimin nedeni, 2002/584 sayılı Çerçeve Karar'ın özgürlük, güvenlik ve adalet alanında karşılıklı tanıma ve güven ilkelerini uygulayan ilk somut önlemi oluşturması kadar (Dibace, para. 6), karşılıklı güven ilkesi ve temel haklar arasındaki ilişki bakımından pek çok kez odak noktasını da oluşturmasıdır (Bu yönde bkz. Lenaerts, 2017: 814; Montaldo, 2016: 967).

Çalışma bu amaçla üç bölüm halinde kurgulanmıştır. Birinci bölümde, ATM'ye ilişkin 2002/584 sayılı Çerçeve Karar, karş1lıklı tanıma ilkesi ve onun temelindeki karşılıklı güven ilkesinin işleyişi hakkında fikir verebilmek adına kısaca ortaya konulacaktır. İkinci bölümde, ATM söz konusu olduğunda karş1lıklı güven ilkesinin mutlak bir karine oluşturduğu izlenimi veren ABAD'ın ilk dönem içtihat hukuku ele alınacak ve bunun olası nedenleri üstünde durulacaktır. Üçüncü bölümde, ATM yönünden karşılıklı güven ilkesinin çürütülebilir bir karineye dönüştüğü $A B A D$ ’n son dönem içtihat hukuku incelenecek ve bunun olası nedenleri kadar sonuçları da gösterilmeye çalışılacaktır.

\section{Karşılıklı Güven İlkesi Temelli İlk Araç Olarak Avrupa Tutuklama Müzekkeresi}

Karş1lıkı tanıma ilkesi ve ona temel teşkil eden karşılıklı güven ilkesini somutlaştırmak için, "ceza hukuku alanında bu [ilkeleri] uygulayan ilk somut önlem" olarak nitelendirilen ATM'ye ilişkin 2002/584 sayılı Çerçeve Karar (Dibace, para. 6) ana hatlarıyla ortaya konacaktır (ATM ile ilgili genel olarak bkz. Erdem, 2004: 314-28; Gündoğdu, 2018: 68 vd. ve Peers, 2012: 696-710).

ATM'ye uzanan tarihsel gelişim sürecine baktığımızda, ilk tespit, karşılıklı tanıma ilkesinin adli işbirliği alanında en baştan beri değil, sonradan bir yöntem olarak benimsenmiş olmasıdır. Adli işbirliği, ilk kez, ABA'nın ([1992] OJ C 191/1) K.1/6 ve 7. maddesi ile getirildiğinde K.3. maddesi bu alanda üye devlet eylemlerinin eşgüdümü üstünde durmaktaydı. Amsterdam Antlaşması ile değişik ABA'nın ([1997] OJ C 340/145) 29. maddesindeyse "Birliğin hedefinin vatandaşlarına özgürlük, güvenlik ve adalet alanı içerisinde yüksek düzey emniyet sunmak olduğu", bunun -diğerlerinin yanında- "üye devletlerin yargisal...otoriteleri arasında yakın işbirliğ $\imath$ " aracılığıla olacağ belirtilmekteydi. 15-16 Ekim 1999 tarihli Tampere Zirvesi bu alandaki kırılma noktası olmuştur. Zirve Sonuç Bildirgesinin 33 ve 35. noktalarına göre: "Zirve, Birlik içindeki hem hukuki hem de cezai konulardaki adli işbirliğinin köşe taşı olması gerektiğini düşündüğü karşılıklı tanıma ilkesini benimser", dahası cezai konularda adli işbirliğinde “...iade prosedürü ortadan kaldırılmalı, ... onun yerine [ilgili] kişilerin basitçe transferi geçmelidir”. ATM ile ilgili çalışmalar 
bu arka planda başlatılmakla beraber, bu çalışmaların seyri 11 Eylül 2001 olayları ile esaslı biçimde değişmiş, ATM Çerçeve Kararı bu olayları takiben hızla benimsenmiştir (Bu yönde bkz. Wouters ve Naert, 2004: 911-12). Karşılıklı tanıma ilkesi ise, Lizbon Antlaşması ile değişik ABİHA ([2012] OJ C 326/47) 67(3), 70, 81 ve 82. maddelerinin gösterdiği gibi, başta adli işbirliği olmak üzere özgürlük, güvenlik ve adalet alanının köşe taşı olma vasfını güçlendirmiştir.

ATM ile ilgili bilgilerden evvel, çeviride "tutuklama" teriminin neden tercih edildiği üstünde kısaca durulabilir. Öncelikle hatırlatmak gerekir ki "[Birlik] hukuku kendine özgü bir terminoloji kullanır" ve "hukuki terimler, [Birlik] hukuku ile çeşitli üye devletlerin hukuklarında aynı anlama gelmeyebilir" (CILFIT v Ministero della Sanità, Case 283/81, 1982, para. 19). Ayrıca, Türkçe $\mathrm{AB}$ resmi dilleri arasında yer almadığından, terim tercihleri gayri resmi bir nitelik taşımanın ötesine geçemeyecektir. $\mathrm{Bu}$ arka planda, tercih edilen "tutuklama" terimi, AB hukuku ile Türk hukukunda aynı anlama gelmeyecektir. Aşağıda detaylı olarak görüleceği üzere, özünde, ATM ile bir üye devlet bir kişiyi talep etmekte, diğer üye devlet de ATM çerçevesinde o kişiyi o devlete teslim edip etmeme yönünde bir karar almaktadır (md. 1(1)). Diğer üye devlet, bu karara varacağı zaman dilimi açısından, talep edilen kişiyi tutuklu tutabileceği gibi, o kişinin kaçmasını engellemek ve etkili biçimde teslimi için gerekli maddi koşulların karşılanmaya devam etmesini sağlamak için gerekli gördüğü tüm tedbirleri almak şartıyla, o kişiyi herhangi bir zamanda geçici olarak serbest de birakabilir (md. 12 ve Minister for Justice and Equality $v$ Francis Lanigan, Case C-237/15 PPU, 2015, para. 61). O halde, konuya Türk hukuku açısından yaklaşıldığında, ATM çerçevesinde, bir kişiyi özgürlüğünden yoksun bırakan, dolayısıyla alınabilecek en ağır koruma tedbiri olan, tutuklama dâhil (Bkz. JZ v Prokuratura Rejonowa Łódź - Śródmieście, Case C-294/16 PPU, 2016, para. 45), yakalama ve gözaltı ile adli kontrol gibi koruma tedbirleri de söz konusu olabilecektir (Krş. 6706 sayılı Cezaî Konularda Uluslararası Adlî İş Birliği Kanunu md. 14, 16, 20, 5 ve bkz. 5271 sayılı Ceza Muhakemesi Kanunu md. 90-115). ATM, bu içerik itibariyle Türk hukukundaki hukuki terimlerden herhangi birisi ile baştan sona örtüşmediğine göre, hem ATM çerçevesinde alınabilecek koruma tedbirlerinden en ağırı olduğundan hem de ATM'nin kimi maddeleri bu koruma tedbirinin uygulamada yaygın olarak kullanılacağı varsayımı altında kaleme alındığından (örneğin bkz. md. 12 veya 26), "tutuklama" teriminin çeviride tercihinin en uygunu olacağ değerlendirilmiştir.

ATM, 7 Ağustos 2002 tarihinde yürürlüğe giren ve iç hukuka aktarılmak üzere 31 Aralık 2003 tarihini öngören 2002/584 sayılı Çerçeve Karar ile getirilmiştir (md. 35 ve 34(1)). ATM, cezai kovuşturma yürütmek veya hürriyeti bağlayıcı cezayı ya da tutuklama kararını infaz etmek amaçlarıyla bir 
üye devlet tarafindan talep edilen kişinin bir başka üye devlet tarafindan tutuklanması ve teslimi maksadıyla çıkarılan yargısal karardır (md. 1(1)). O hâlde ATM'yi bir "çıkaran" bir de "yürüten" "yargısal makam" vardır (md. 6(1 ve 2)): Çıkaran yargısal makam, çıkaran üye devletin hukuku aracılığıyla ATM çıkarmaya yetkili olan o üye devletin yargısal makamıdır. Yürüten yargısal makam ise, yürüten üye devletin hukuku aracılığıyla ATM'yi yerine getirmeye yetkili olan o üye devletin yargısal makamıdır. Yargısal makam ise, Birlik hukuku kavramı olup yalnızca bir üye devletin hâkiminin veya mahkemesinin tayini ile sınırlı değildir, fakat ilgili hukuk sisteminde adaleti yerine getirmeye katılması gereken diğer makamlara da genişletilebilir (örneğin bkz. PF, Case C509/18, para. 57, krş. $O G$, Joined cases C-508/18 and C-82/19 PPU, para. 90), ancak örneğin bir Bakanlık veya polis teşkilatı gibi bir üye devletin idari makamını kapsıyor şekilde yorumlanamaz (Openbaar Ministerie v Ruslanas Kovalkovas, Case C-477/16 PPU, 2016, para. 32-35; Openbaar Ministerie v Krzysztof Marek Poltorak, Case C- 452/16 PPU, 2016, para. 31-34).

ATM'nin kapsamı ile ilgili üç tespit yapılabilir (md. 2). Birincisi, ATM, yalnızca, çıkaran üye devletin hukukuna göre azami süre olarak en az 12 ay hürriyeti bağlayıcı ceza ya da tutuklama kararı ile cezalandırılabilir eylemler için veya hüküm verildiyse ya da tutuklama kararı alındıysa en az 4 aylık mahkûmiyetler için çıkarılabilir (Bkz. Openbaar Ministerie v A, Case C-463/15 PPU, 2015, para. 29-30). İkincisi, 2002/584 sayılı Çerçeve Karar'da sayılan 32 suç türü (örneğin terörizm, insan kaçakçılığ 1 , ırkçılık ve yabanc1 düşmanlığ1 vb.), eğer çıaran üye devlette azami süre olarak en az 3 yıl hürriyeti bağlayıcı ceza ya da tutuklama kararı ile cezalandırılabilir nitelikteyse ve çıkarıcı üye devletin hukukunda tanımlandığı haliyle, ilgili eylemin her iki üye devlette de suç oluşturup oluşturmadığına bakılmaksızın, ATM uyarınca teslime sebebiyet verir. Üçüncüsü, 2002/584 sayılı Çerçeve Karar' da sayılan 32 suç türü dışındaki suçlar bakımından teslim, ATM'nin çıkarıldığı eylemlerin yürüten üye devletin hukukunda da suç oluşturması koşuluna tabi tutulabilir.

Çalışmanın konusu açısından kilit nokta "[ATM] mekanizmasının üye devletler arasında yüksek düzey itimada dayalı olduğu"nu gösteren ATM'yi yerine getirme yükümlülüğü ile ilgilidir (Dibace, para. 10). Kural olarak, üye devletler, her ATM'yi karşılıklı tanıma ilkesi temelinde ve 2002/584 sayılı Çerçeve Karar'in hükümlerine uygun olarak yerine getirir (md. 1(2). Bkz. $A Y$, Case C-268/17, 2018, para. 32-36). Başka bir ifadeyle, ATM, yürüten yargısal makam tarafından, kural olarak, otomatikman yerine getirilmelidir. Buna karşın, üye devletler, birtakım zorunlu veya seçimlik sebepler temelinde ATM'yi yerine getirmeyebilir, dahası belirli hallerde ATM'yi çıkaran üye devletten birtakım güvenceler isteyebilir, ancak aşağıda görüleceği üzere, 2002/584 sayılı Çerçeve Karar, Dibace paragraf 12 ve 13 ile 1(3). maddesindeki gönderme dışında, temel hakların korunması ile ilgili zorunlu veya seçimlik bir ret sebebi 
veya güvence isteme ihtimali içermemektedir ( $\mathrm{Bu}$ yönde bkz. Miettinen, 2014: 186; Peers, 2012: 663; Mitsilegas, 2009: 128).

Zorunlu sebepler ile ilgili olarak yürüten üye devletin yargısal makamı şu hallerde ATM'yi yerine getirmeyi geri çevirir (md. 3):

(i) ATM'nin çıkarılmasına neden olan suç, yürüten üye devletin kendi ceza hukuku uyarınca bu suçu kovuşturma yetkisi olduğu hallerde, yürüten üye devlette çıkartılan genel af kapsamı içerisinde yer almaktaysa,

(ii) yürüten yargısal makam talep edilen kişinin aynı eylemler bakımından bir üye devlette yargılanmasının tamamlandığından, dahası ortada o kişi hakkında verilmiş bir hüküm olduğu hallerde, ceza çekildiğinden veya çekilmekte olduğundan ya da cezayı veren üye devletin hukuku uyarınca artık infaz edilemiyor olduğundan haberdar edilirse (Bkz. Gaetano Mantello, Case C-261/09, 2010, para. 32-51 ve $A Y$, Case C-268/17, 2018, para. 38-46),

(iii) ATM'nin konusu olan kişi yaşı nedeniyle ATM'nin temel aldığı eylemler açısından yürüten üye devletin hukuku uyarınca cezai olarak sorumlu tutulamiyorsa.

Seçimlik sebepler ile ilgili olarak yürüten üye devletin yargısal makamı şu hallerde ATM'yi yerine getirmeyi geri çevirebilir (md. 4 ve 2009/299 sayilı Çerçeve Karar ile değişik md. 4a):

(i) ATM'nin çıkarılmasına neden olan eylem, 2002/584 sayılı Çerçeve Karar'da sayılan 32 suç türü dışında kalıyorsa ve yürüten üye devletin hukukuna göre bir suç oluşturmuyorsa (aynı fikrada vergi veya harçlar, gümrük veya döviz vergileri ile ilgili özel düzenleme mevcuttur),

(ii) ATM'nin konusu olan kişi yürüten üye devlette ATM'nin temel aldığ1 eylem ile aynı eylem nedeniyle kovuşturuluyorsa (Bkz. AY, Case C-268/17, 2018, para. 47-62),

(iii) yürüten üye devletin yargısal makamları ATM'nin temel aldığı suç yönünden kovuşturmaya yer olmadığına veya kovuşturmayı durdurmaya karar verdiyse ya da bir üye devlette talep edilen kişi hakkında aynı eylemler bakımından nihai karar verildiyse ve bu, kovuşturmayı devam ettirmeyi engelliyorsa,

(iv) talep edilen kişinin cezai kovuşturması veya cezalandırılması yürüten üye devletin hukuku uyarınca zaman aşımına uğradıysa ve yürüten üye devletin kendi ceza hukuku uyarınca eylemler o devletin yargılama yetkisi içinde kaliyorsa,

(v) eğer yürüten yargısal makam talep edilen kişinin aynı eylemler bakımından bir üçüncü devlette yargılanmasının tamamlandığından haberdar 
edilirse ve ortada hüküm olması halinde ceza çekildiyse veya çekiliyorsa ya da cezayı veren devletin hukuku uyarınca artık infaz edilemiyorsa,

(vi) ATM, hürriyeti bağlayıcı cezanın ya da tutuklama kararının infazı amacıyla çıkarıldıysa ve talep edilen kişi, yürüten üye devlette kalıyor veya mukim veya o devletin vatandaşıysa ve o devlet kendi hukukuna uygun olarak o cezayı ya da kararı infaz etmeyi üstleniyorsa (Bkz. Proceedings concerning the execution of a European arrest warrant issued against Szymon Kozłowski, Case C-66/08, 2008, para. 29-54; Proceedings concerning the execution of a European arrest warrant issued against João Pedro Lopes Da Silva Jorge, Case C-42/11, 2012, para. 27-60),

(vii) ATM, yürüten üye devletin hukukuna göre o devletin ülkesinde veya böyle sayılan bir yerde tamamen veya kısmen işlenmiş olarak nitelenen türde bir suça ya da çıkaran üye devletin ülkesinin dışında işlenen ve yürüten üye devletin hukukunun kendi ülkesi dışında işlendiğinde aynı suçlar için kovuşturma izni vermediği türde bir suça ilişkinse,

(viii) ATM'nin hürriyeti bağlayıcı cezanın ya da tutuklama kararının infazı amacıyla çıkarıldığı hallerde, ilgili kişi bu karar ile sonuçlanan duruşmada bizzat bulunmadiysa ve ATM ile bu bizzat bulunmamaya ilişkin 2009/299 sayılı Çerçeve Karar ile değişik md. 4(a)'daki koşullardan herhangi birinin var olduğu belirtilmediyse (Bkz. Openbaar Ministerie v Pawet Dworzecki, Case C108/16 PPU, 2016, para. 25-54).

Güvenceler ile ilgili olarak yürüten yargısal makam kendi hukuku çerçevesinde ATM'yi yerine getirmeyi şu hallerde şu koşullara tabi tutabilir (md. 5):

(i) ATM'nin temel aldığg suç, ömür boyu hapis cezası veya ömür boyu tutukluluk kararı ile cezalandırılabilirse bu müzekkerenin yerine getirilmesi, çıkaran üye devletin kendi hukuk sisteminde talep üzerine veya en geç 20 y1l sonunda vaz edilen cezanın veya önlemin gözden geçirilmesine ya da ilgili kişinin çıkaran üye devletin hukuku ya da uygulaması uyarınca başvurmaya hakkı olan ve bu tür cezanın veya önlemin infaz edilmemesini amaçlayan özel af önlemlerinin uygulanmasına ilişkin kuralların bulunması şartına tabi tutabilir.

(ii) Kovuşturma amaçlarıyla ATM'nin konusu olan kişi yürüten üye devletin vatandaşı veya mukimi ise teslim, ilgili kişinin, dinlenildikten sonra, çıkaran üye devlette hakkında alınan hürriyeti bağlayıcı cezayı ya da tutuklama kararını çekmek üzere yürüten üye devlete geri gönderilmesi şartına tabi tutulabilir.

ATM sisteminin işleyişi ile ilgili kurallar üç aşamada ele alınabilir. Birinci aşamada ATM çıkarılır. Çıkarıcı yargısal makam, belli bir içerikle ve biçimle ATM'yi çıkarır (md. 8) ve eğer talep edilen kişinin yeri biliniyorsa ATM'yi yürüten yargısal makama doğrudan iletebilir veya her hâlükârda Schengen Bilgi 
Sistemine talep edilen kişi için bir uyarı koymaya karar verebilir (md. 9(1 ve 2)). İkinci aşamada talep edilen kişi yakalanır ve hakkında ATM gereği işlem yapılır. Yürüten yargısal makam, talep edilen kişi yakalandığında öncelikle ulusal hukukuna uygun olarak o kişiyi içeriğiyle birlikte ATM'den ve çıkarıcı yargisal makama teslime rıza gösterebileceğinden haberdar eder (md. 11(1)). $\mathrm{Bu}$ kişi, yürüten üye devletin hukukuna uygun olarak bir hukuki danışmanın ve tercümanın yardımını alma hakkına sahiptir (md. 11(2)). Yürüten yargısal makam, kendi hukukuna uygun olarak talep edilen kişinin tutuklu kalmasının gerekip gerekmediği hakkında bir karar verir ve o kişinin kaçmasını engellemek için gerekli gördüğü tüm tedbirleri almak şartıyla o kişiyi herhangi bir zamanda geçici olarak serbest bırakabilir (md. 12). Yürüten yargısal makam, eğer yakalanan kişi kendi hukukuna uygun olarak ve önünde teslime rıza gösterirse ve duruma göre "özellik kuralı" hakkından açıkça feragat ederse teslime ilişkin kararı alır (md. 13(1)). Yürüten yargısal makam, eğer yakalanan kişi teslime rıza göstermiyorsa bu kişiyi kendi hukukuna uygun olarak dinledikten sonra (md. 14) 2002/584 sayılı Çerçeve Karar'daki zaman sınırlamaları ve koşullar altında bu kişinin teslim edilip edilmemesine ilişkin bir karar verir (md. 15(1)). Üçüncü aşamada talep edilen kişi teslim edilir. Bu halde, teslim edilen kişi, kural olarak, "özellik kuralı" gereği teslim tarihinden önce işlediği ve teslim edildiği suçtan farklı bir suçtan ötürü kovuşturulamaz, cezalandırılamaz veya hürriyetinden yoksun bırakılamaz (md. 27(2)). Ayrıca, çıkarıcı üye devlet, teslim edilen kişiye verilecek hürriyeti bağlayıcı cezanın ya da tutuklama kararının sonucu olarak kendi devletinde çekilecek tutukluluk süresinden ATM'nin yerine getirilmesinden kaynaklanan tutukluluk sürelerini düşer (md. 26(1). Bkz. JZ v Prokuratura Rejonowa Łódź - Śródmieście, Case C-294/16 PPU, 2016, para. 31-57).

ATM, kural olarak, otomatikman yerine getirileceği için zaman sınırlamaları ve prosedürler ile de çevrelenmiştir (md. 17): Birincisi, ATM, acil konu olarak ele alınır ve yerine getirilir. İkincisi, talep edilen kişinin teslimine rıza gösterdiği hallerde ATM'nin yerine getirilmesine ilişkin nihai karar rızanın verilmesini takiben 10 gün içinde alınmalıdır. Üçüncüsü, talep edilen kişinin teslimine rıza göstermediği hallerde ATM'nin yerine getirilmesine ilişkin nihai karar talep edilen kişinin yakalanmasını takiben 60 gün içinde alınmalıdır. Dördüncüsü, yürüten yargısal makam, spesifik hallerde ATM yukarıdaki 10 ve 60 günlük süreler içinde yerine getirilemiyorsa gecikme nedenlerini de belirterek çıkaran yargısal makamı hemen durumdan haberdar eder ve zaman sınırlamaları 30 gün daha uzatılabilir. Bununla beraber, yürüten üye devlet, buradaki zaman sınırlamaları salt aşıldı diye ATM'yi yerine getirme yükümlülüğünden kurtulmaz (Minister for Justice and Equality v Francis Lanigan, Case C-237/15 PPU, 2015, para. 42), başka bir ifadeyle bu zaman sınırlamaları düzenleyici sürelerdir. Son olarak, talep edilen kişi, ATM'nin yerine getirilmesi nihai kararını takiben 10 gün içinde ve ilgili makamlar 
arasında anlaşılan tarihte teslim edilir (md. 23(1 ve 2). (Bkz. Minister for Justice and Equality v Tomas Vilkas, Case C-640/15, 2017, para. 74).

Özetle ATM, kâğıt üstünde karşılıklı tanıma ilkesi gereği yürüten yargısal makam tarafından, çıkaran üye devlet ile ilgili temel hakların korunmasına yönelik genel bir ret sebebi veya güvence söz konusu olmaksızın, karşılıklı güven ilkesi temelinde, kural olarak, otomatikman yerine getirilmelidir. Peki, ama uygulamada neler olmuştur?

\section{Karşılıklı Güven İlkesi Mutlak Karine Midir: Avrupa Tutuklama Müzekkeresi Uygulamasının İlk Dönemi}

ABAD, ATM uygulamasının ilk döneminde karşılıklı güven ilkesi ile temel hakların korunması arasındaki dengeyi karşılıklı güven ilkesi lehine kurmuştur.

ABAD, ancak 2010'lı yıllarda Radu kararı ile birlikte karş1lıklı tanıma ve güven ilkesi ile temel hakların korunması arasındaki ilişki üzerinde açıkça durmuştur. $\mathrm{Bu}$ davada (Proceedings relating to the execution of European arrest warrants issued agains Ciprian Vasile Radu, Case C-396/11, 2013, para. 16-20), farklı Alman mahkemeleri, Bay Radu hakkında yürütülmekte olan cezai muameleler bağlamında dört farklı ATM çıkarmıştır. Constanţa (Romanya) mahkemesi ise, yürüten yargısal makam olarak bu müzekkereleri yerine getirirken Bay Radu'nun temel haklar temelli itirazları ile karşılaşmıştır. Bay Radu'ya göre çıkaran yargısal makamlar ABTHŞ md. 47 ve 48 ile AİHS md. 6'ya aykırı olarak Bay Radu'yu önceden dinlemeksizin ATM çıkarmış olduğundan kendisinin teslim edilmemesi gerekir. Ulusal mahkeme, ABAD'a ön karar başvurusu yaparak 2002/584 sayılı Çerçeve Karar ile temel haklar arasındaki ilişki ile ilgili sorular yöneltmiştir.

Hukuk Sözcüsü (HS) Sharpston, Radu davasındaki 18 Ekim 2012 tarihli Görüşü ile karşılıklı tanıma ve güven ilkesi ile temel hakların korunması arasında denge kurmaya çalışmıştır. Ona göre (Proceedings relating to the execution of European arrest warrants issued agains Ciprian Vasile Radu, Case C-396/11, 2012, pt. 97) yürüten yargısal makam, "teslimi istenen kişinin temel haklarının teslim sürecinin bir parçası olarak veya teslim sürecini takiben ihlal edildiği veya ihlal edileceği gösterildiğinde, ..., teslim talebini geri çevirebilir, ancak bu yalnızca istisnai durumlarda geçerli olacaktır". Örneğin ABTHŞ md. 6, 47 ve 48 açısından "ihtilaflı ihlal sürecin adilliğini özünde ortadan kaldırmalı" olup "ihlal iddiasındaki kişi, itirazlarının esaslı biçimde temellendirilmiş olduğu konusunda karar alıcıyı ikna etmelidir”.

ABAD ise, Büyük Daire olarak 29 Ocak 2013 tarihinde verdiği Radu kararında HS Görüşünden ayrılmıştır. ABAD'a göre (Proceedings relating to the execution of European arrest warrants issued agains Ciprian Vasile Radu, Case C-396/11, 2013, para. 31, 34, 36-38 ve 43) esas soru şudur: Yürüten 
yargısal makam, 2002/584 sayılı Çerçeve Karar ABTHŞ md. 47 ve 48 1şı̆̆ında ele alındığında, cezai kovuşturma yürütmek amacıyla çıkarılan ATM'yi yerine getirmeyi çıkarıcı yargısal makamın ATM çıkarılmadan evvel talep edilen kişiyi dinlemediği gerekçesiyle geri çevirebilir mi? Bu Çerçeve Karar, ceza hukukunu ihlal etmekten hükümlü veya şüpheli kişilerin teslimi için yeni bir basitleştirilmiş ve daha etkili sistem getirerek AB'nin bir özgürlük, güvenlik ve adalet alanı olması hedefine katkıda bulunmak amaciyla ve üye devletler arasında var olması gereken yüksek derecede itimadı temel alarak yargısal işbirliğini kolaylaştırmayı ve hızlandırmayı amaçlar. Üye devletler, ilke olarak, ATM'ye göre hareket etmekle yükümlü olup yalnızca zorunlu veya seçimli yerine getirmeme sebeplerinden birisi ile böyle bir müzekkerenin yerine getirilmesini geri çevirebilir. Hüküm verilen ya da tutuklama kararı alınan hallerin aksine, cezai kovuşturma yürütmek amacıyla ATM çıkarılmadan evvel talep edilen kişinin dinlenmemesi ise böyle bir sebep oluşturmaz, dolayısıyla yürüten yargisal makam ATM'nin yerine getirilmesini buna dayanarak geri çeviremez.

Peki, HS Sharpston ve Adalet Divanı, hangi noktalarda birbirlerinden ayrılmış gözükmektedir? HS Sharpston'a göre, özetle, teslimi istenen kişi, temel haklar ihlaline geçmişte uğradığı veya gelecekte uğrayacağı yönünde itirazda bulunabilir ve iddiasını ispatla yükümlüdür, dahası temel hak ihlali eşiği (özünü ortadan kaldırma) ve ispat yükü eşiği (esaslı biçimde temellendirme) yüksektir. Bu bakımdan, ATM açısından karşılıklı güven esastır, ancak istisnai durumlar olabilir. Adalet Divanının kararı ise birden çok şekilde okunabilir. Birincisi, Radu kararı ATM'nin, zorunlu veya seçimli yerine getirmeme sebeplerinden birisi olmaksızın, temel hak ihlali iddiası olsa bile karşılıklı güven ilkesi temelinde mutlaka yerine getirilmesi gerektiği şeklinde okunabilir ( $\mathrm{Bu}$ yönde bkz. Brouwer, 2016: 915; Miettinen, 2014: 186 ve Montaldo, 2016: 976). İkincisi, Radu kararı Adalet Divanının, ATM'ye ilişkin tasarruf uyuşmazlık konusu hakkında standardı belirlediğinden (cezai kovuşturma yürütmek amacıyla ATM çıkarılmadan evvel talep edilen kişinin dinlenmeyebilmesi) ve bu standart temel haklar ile uyumlu olduğundan, temel hak ihlali nedeniyle teslime itiraz ile ilgili olumlu veya olumsuz başka bir tespitte bulunmadığı şeklinde okunabilir (Bu yönde bkz. Janssens, 2013: 208. Krş. Gill-Pedro ve Groussot, 2017: 268; Lenaerts 2017: 817). Bu ikinci okuma, Adalet Divanının Büyük Daire olarak 26 Şubat 2013 tarihinde verdiği Melloni kararının içeriği ile de uyuşmaktadır (Stefano Melloni v Ministerio Fiscal, Case C-399/11, 2013, para. 45, 46 ve 54. Bu yönde bkz. Janssens, 2013: 188 ve 209; Mitsilegas, 2016: 158).

ABAD'1n, özellikle 2013 tarihli Radu ve Melloni kararları dikkate alındığında, o dönemki eğilimin uzağında kaldığı tespiti yapılabilir. Örneğin Alman Anayasa Mahkemesi, daha 18 Temmuz 2005 tarihinde, ATM'yi iç 
hukuka aktaran ulusal mevzuat ile ilgili olarak “...katı bir karşılıklı tanıma ilkesini, onunla bağlantılı olan devletler arasında karşılıklı güvene ilişkin kapsamlı önermelerle birlikte uygulamaya koymak, temel haklara ilişkin anayasal güvenceleri kısıtlayamaz" ve "kişilerin iadesi bakımından... Anayasa, her bir bireysel davada [ilgili] kişinin uygun olan haklarının güvenceye alınıp alınmadığının spesifik incelenmesini gerektirir" ş̧eklinde karar vermiştir (BVerfG, Order of the Second Senate of 18 July 2005 - 2 BvR 2236/04 - para. 118 ve 88). Yine üye devletlerden üçte ikisi, daha en başından, 2002/584 sayılı Çerçeve Kararı iç hukuka aktarırken ATM'nin temel hak ihlali temelinde geri çevrilme ihtimaline ulusal mevzuatında yer vermiştir (COM(2005) 63 final: 5). Komisyon ise, başta bu uygulama ile ilgili net tavır takınmakta zorlanmışsa da (COM(2005) 63 final: 5), 2011 y1lının Nisan ayında "ATM sisteminin [özellikle temel haklar üstündeki etkileri dikkate alındığında] mükemmel olmaktan uzak" olduğu noktasına gelmiştir (COM/2011/0175 final: 3). Zira AİHM, 2011 yılının Ocak ayında Büyük Daire olarak verdiği ve doğrudan ATM ile ilgili olmasa bile ATM gibi karşılıklı güven ilkesi temelinde işleyen Dublin II Tüzüğü ([2003] OJ L 50/1) ile ilgili M.S.S. v. Belgium and Greece kararı ile AİHS'nin 3. maddesinin -kötü muamele yasağının- bir kişiyi bir başka ülkeye göndermeme yükümlülüğü içerebileceğini ortaya koymuştur (M.S.S. v. Belgium and Greece, No. 30696/09, 2011). İşte Komisyonun 2011 yılının Nisan ayındaki raporuna göre de 2002/584 sayılı Çerçeve Karar'ın 1(3). maddesi gereği "yürüten yargısal makam somut uyuşmazlığın tüm vakalarını göz önüne alarak teslimin ilgili kişinin temel haklarını ihlal edeceğine kani olduysa" teslim yükümlülük olmaktan çıkmalıdır (COM/2011/0175 final: 7).

Peki, ABAD neden dönemin eğilimine uzak durmuş olabilir? Birincisi, ABAD, ileride (bir tür) anayasal ilke olarak nitelendireceği karşılıklı güven ilkesinin yerleşmesini sağlamak amaciyla böyle hareket etmiş olabilir $(\mathrm{Bu}$ yönde bkz. Ostropolski, 2015: 175 ve 175-76). Bu yönden ABAD’ın karş1lıklı güven ilkesine yaklaşımı ile örneğin doğrudan etki ilkesi gibi diğer anayasal ilkelere yaklaşımı arasında belirli bir ölçüde paralellik kurulabilir. ABAD, doğrudan etki ilkesi söz konusu olduğunda da baştan ilkenin tesisi adına net bir tutum takınmış (Örneğin bkz. Yvonne van Duyn v Home Office, Case C-41/74, 1974, para. 12-15), ancak özellikle ulusal mahkemelerden gelen baskıy1 kırabilmek adına zaman içinde bu tutumunu esnetme yoluna gitmiştir (Örneğin bkz. M. H. Marshall v Southampton and South-West Hampshire Area Health Authority (Teaching), Case C-152/84, 1986, para. 46-48, 51). İkincisi, ABAD, proaktif değil, reaktif bir mahkeme olduğundan karşılıklı güven ilkesi ile temel haklar arasında denge kurmak istemiş olsa bile, önüne böyle bir dengeleme faaliyetine girişebileceği türde bir somut uyuşmazlık getirilmemiş olabilir $(\mathrm{Bu}$ yönde bkz. Janssens, 2013: 209. Krş. Willems, 2016: 224). Not düşmek gerekir ki 2010 yilındaki I.B. davasında ulusal mahkeme, ABAD'a ön karar başvurusu yaparak açıkça “[ATM'nin] uygulanmasının ilgili kişinin temel haklarını ihlal 
etme etkisine sahip olacağına inanmak için geçerli sebepler varsa [ATM'nin] uygulanması geri çevrilebilir mi" sorusunu sormuştur (I.B., Case C-306/09, 2010, para. 41). ABAD ise, 21 Ekim 2010 tarihli kararında "teslimi 2002/584 sayılı Çerçeve Kararın 5(3). maddesinin öngördüğü güvenceye bağlamanın mümkün olduğu kabul edildiğine göre [ilgili soruya] yanıt vermek gerekli değildir" diyerek bu açık soruyu yanıtsız bırakmıştır (I.B., Case C-306/09, 2010, para. 63). Öyleyse I.B. davasının ve kararının mevcudiyeti, bu paragrafta ele alınan birinci sebebi ikinci sebebe oranla daha baskın bir sebep k1lyor denilebilir.

ABAD, bu arka planda, karşılıklı güven ilkesi ile temel hakların korunması arasındaki dengeye ilişkin ilk kararını ancak 2016 yılında verebilmiştir.

\section{Karşılıklı Güven İlkesi Çürütülebilir Karine Midir: Avrupa Tutuklama Müzekkeresi Uygulamasının Son Dönemi}

ABAD, ATM uygulamasının son döneminde karşılıklı güven ilkesi ile temel hakların korunması arasındaki makul dengeyi bulmaya çalışmaktadır.

ABAD, ilk kez, Büyük Daire olarak 5 Nisan 2016 tarihinde verdiği Aranyosi and Căldăraru kararı ile karşılıklı güven ilkesi ile temel hakların korunmasını dengeleyecek bir test geliştirmiştir. Bu davada (Pál Aranyosi and Robert Căldăraru v Generalstaatsanwaltschaft Bremen, Joined cases C-404/15 and 659/15 PPU, 2016, para. 28-46 ve 47-63), Miskolc (Macaristan) mahkemesi, 4 Kasım ve 31 Aralık 2014 tarihlerinde Bay Aranyosi hakkında kovuşturma yürütmek amacıyla ATM çıkarmıştır. Fagaras (Romanya) mahkemesi de, 29 Ekim 2015 tarihinde Bay Căldăraru hakkında hürriyeti bağlayıcı cezayı infaz etmek amacıyla ATM çıkarmıştır. Yürütücü yargısal makam olarak Bremen (Almanya) mahkemesine göre ise Macaristan ve Romanya yargısal makamlarına teslimin gerçekleşmesi halinde, Bay Aranyosi'nin ve Bay Căldăraru'nun, kötü muamele yasağını ihlal eden tutukluluk koşullarına tabi tutulabileceğine ilişkin ispatlayıcı deliller mevcuttur. Bremen mahkemesi, ABAD'a ön karar başvurusu yaparak böyle bir durumda 2002/584 sayılı Çerçeve Karar çerçevesinde nasıl bir tutum takınılması gerektiği ile ilgili sorular yöneltmiştir.

ABAD, Büyük Daire olarak 5 Nisan 2016 tarihinde verdiği Aranyosi and Căldăraru kararı ile temel hakların korunmasını karşılıklı güven ilkesi denklemine dâhil etmiştir. ABAD'a göre (Pál Aranyosi and Robert Căldăraruv Generalstaatsanwaltschaft Bremen, Joined cases C-404/15 and 659/15 PPU, 2016, para. 89 ve 94, 95 ve 97, 104) birincisi, 2002/584 sayılı Çerçeve Kararın yorumu uyarınca "çıkaran üye devletteki tutukluluk koşullarına ilişkin olarak sistematik veya genellenmiş olabilecek ya da belirli bir grup insanı etkileyebilecek ya da belirli tutukluluk yerlerini etkileyebilecek eksikliklerin olduğunu gösteren nesnel, güvenilir, spesifik ve uygun biçimde güncellenen 
bilgi" söz konusuysa "yürüten yargisal makam, ... [ATM'nin] konusu olan kişinin çıkarıcı üye devletteki tutukluluğunun koşulları nedeniyle bu üye devlete teslimi halinde ABTHŞ md. 4 anlamında insanlık dışı veya alçaltıcı muameleye yönelik gerçek bir risk ile karşı karşıya kalacağına inanmak için esaslı sebepler olup olmadığını belirlemelidir”. İkincisi, yürüten yargısal makam, bu amaçla, çıkarıcı yargısal makam tarafından ek bilgi sunulmasını talep etmeli, çıkaran yargısal makam da, bu talepte belirtilen zaman sinırı içerisinde bu bilgiyi göndermelidir. Üçüncüsü, "yürüten yargısal makam, böyle bir riskin varlığının ortadan kalkmasını sağlayacak ek bilgiyi alana kadar ilgili bireyin teslimi kararını ertelemeli" ve "eğer böyle bir riskin varlığı makul süre içerisinde ortadan kalkmıyorsa teslim prosedürünün sonlandırılması gerekip gerekmediğine" ilişkin karar almalıdır.

Peki, ABAD, Aranyosi and Căldăraru kararı ile birlikte neden tutum değişikliğine gitmiş olabilir? Birincisi, reaktif bir mahkeme olan ABAD, önceki davalardan farklı olarak, Aranyosi and Căldăraru davası ile birlikte karşılıklı güven ilkesi ile temel haklar arasındaki dengeye ilişkin söz söylemek açısından net bir fırsat yakaladığı gibi, söz söylemekten kaçamayacağı bir durumda da kalmıştır. Bu yönden Radu davası ve Melloni davası, yukarıda da belirtildiği gibi, hem teslim sürecinin sonrası ile değil, öncesi ile ilgili olan hem de 2002/584 sayılı Çerçeve Karar'ın uyuşmazlık konusu ile ilgili standardı belirlediği söylenebilecek olan ve dolayısıyla böyle bir dengeden bahsetme firsatının da bulunmadığı davalar olarak görülebilir. I.B. davası ise, ulusal mahkemenin bu yönde açık sorusu olsa bile ABAD'ın ön karar prosedürünün işleyişi ile ilgili içtihat hukukunu temel alarak o soruyu yanıtsız bırakma şansını yakaladığı bir dava olarak ele alınabilir. İşte Aranyosi and Căldăraru davası, Macaristan'ın ve Romanya'nın cezaevi koşulları nedeniyle, ABAD'ın bir kişinin temel hak ihlali temelinde teslimine itirazı ile ilgili olumlu veya olumsuz bir tespitte bulunmasını gerektiren bir dava olmuştur ( $\mathrm{Bu}$ yönde bkz. Janssens, 2013: 230).

İkincisi, ABAD, karşılıklı güven ilkesini kural olarak yeteri kadar yerleştirdiğini, dolayısıyla artık kontrollü bir geri çekilme vaktinin geldiğini düşünmüş olabilir (Bu yönde bkz. Xanthopoulou, 2018: 498-499). Zira karş1lıklı güven ilkesi, temel hakların korunması ile ilişkisi söz konusu olduğunda, esasen pek çok yönden baskı altındadır. Bu baskının kökleri, bir taraftan, birincil hukukun bir parçası olarak temel haklar ile ikincil hukukun bir parçası olarak Çerçeve Karar arasındaki hiyerarşik ilişkiye uzanmaktadır. AB hukukunun kaynakları arasındaki normlar hiyerarşisi, Çerçeve Karar'ın temel hakların korunmasını dikkate almasını, illa ki, gerektirecekti (Bu yönde bkz. Göçmen, 2013: 166-67; Janssens, 2013: 206; Peers, 2012: 709-710). Bu baskının kökleri, öte taraftan, temel haklar ile öncelik ilkesi arasındaki ilişkiye uzanmaktadır (Bu yönde bkz. Mitsilegas, 2009: 115). Bu yönden birçok üye 
devlet, anayasalarını ve temel hakların korunmasını göz önüne alarak öncelik ilkesi üstünde kimi sınırlamalar getirmekte olup (Baykal ve Göçmen, 2016: 543), $\mathrm{ABAD}$, tarihsel gelişim sürecine bakıldığında $\mathrm{AB}$ hukuk düzeninde temel hakların korunmasını özellikle de öncelik ilkesini korumak adına başlatmıştı (Bu yönde bkz. Baykal, 2010: 391-92; Keskin Ata, 2013: 21-22). Bu nedenle de, ABAD, ulusal mahkemeleri temel hakları gereği gibi dikkate aldığı konusunda, er ya da geç, ikna etmek zorunda kalacaktı (Bu yönde bkz. Woods ve Watson, 2014: 593). Bu baskının kökleri, diğer taraftan, ABAD ile AİHM arasındaki ilişkilere uzanmakta olup (Bu yönde bkz. [2012] OJ C 339; Janssens, 2013: 222 ve Fabbrini ve Larik, 2016: 145-79), buradaki baskı, aşağıda detaylı olarak inceleneceği üzere, önceki baskı nedenlerine nazaran çok daha görünür bir nitelik taşımaktadır. Özetle, ABAD'ın, AİHM içtihat hukuku o yönde olduğu için, zamanla, temel hakların korunmasını karşılıklı güven ilkesi karşısında bir dengeye oturtması gerekecekti (Bu yönde bkz. Janssens, 2013: 222 vd. ve Peers, 2012: 686).

ABAD ile AİHM, kararları aracılığıyla kendi aralarında kurdukları diyaloga bakılırsa, karşılıklı güven ilkesi ile temel hakların korunması arasındaki denge noktası üstünde henüz uzlaşamamıştır. Bu yönden, Aranyosi and Căldăraru kararı, yüksek ihtimalle, bu tartışmaya son verecek, bir başka deyişle AİHM kararları ile karşılıklı güven ilkesi üstünde oluşan baskıyı tam olarak kırabilecek kapasitede bir karar olmaktan ziyade, bu tartışmada sadece bir ara aşamayı ifade etmektedir. Bir başka deyişle, ABAD'ın kontrollü geri çekilmesi aşağıda dört perdeye ayrılarak ele alınacak olup Aranyosi and Căldăraru kararına kadar anlatılanlar ABAD'ın tutum değişikliğinin nedenleri, bu karardan sonra anlatılanlar ise bu karardaki tutum değişikliğinin sonuçları olarak okunabilir.

İlk perdede, AİHM ve ABAD, 2011 yılında arka arkaya ATM gibi karşılıklı güven ilkesi temelinde işleyen Dublin II Tüzüğü ile ilgili kararlar almıştır. AİHM, 21 Ocak 2011 tarihinde M.S.S. v. Belgium and Greece kararını vermiştir: Öz olarak, Belçika, bir sığınmacıyı Yunanistan'da kötü muameleye tâbi tutulmak yönünden gerçek bir risk ile karşı karşıya kalacağına inanmak için sağlam sebepler varken Yunanistan'a gönderirse AİHS'nin 3. maddesini ihlal etmiş olacaktır (M.S.S. v. Belgium and Greece, No. 30696/09, 2011, para. 362368). AİHM, aslında, bu karar ile karşılıklı güven ilkesine temel hakların korunması kaynaklı ilk sınırı da çizmiş olmaktadır. ABAD, benzer bir uyuşmazlığın önüne taşındığı 21 Aralık 2011 tarihli N. S. and Others kararında, AİHM'nin M.S.S. v. Belgium and Greece kararına da göndermede bulunarak, özetle, şöyle demiştir (N. S. v Secretary of State for the Home Department and M. E. and Others $v$ Refugee Applications Commissioner and Minister for Justice, Equality and Law Reform, Joined cases C-411/10 and 493/10, 2011, para. 80, 104 ve 106): Karşılıklı güven ilkesi gereği "bütün üye devletlerdeki bütün sığınmacılara yönelik muamelenin [ABTHŞ ... ve AİHS]'nin 
gereklilikleri ile uyumlu olduğu varsayılmalıdır". Bununla birlikte bu varsayım çürütülebilir: ABTHŞ'nin 4. maddesi uyarınca "üye devletler, ulusal mahkemeler de dâhil, bir sığınmacının [kötü muameleye] maruz kalma gerçek riski ile karşı karşıya kalacağına inanmak için esaslı sebep oluşturan bir diğer üye devletteki iltica prosedüründeki ve sığınmacıları karşılama koşullarındaki sistemik eksikliklerden habersiz olamayacağı durumlarda, o sığınmacıyı [o üye devlete] transfer edemez". Böylelikle ABAD da, bu karar ile karşılıklı güven ilkesine temel hakların korunması kaynaklı ilk sınırı çizmiştir ( $\mathrm{Bu}$ yönde bkz. Arsava, 2017: 12; Janssens, 2013: 207 ve 229; Lenaerts, 2017: 829; Montaldo, 2016: 979 ve Ostropolski, 2015: 173). ATM Dublin Tüzüğü gibi karşılıklı güven ilkesi temelinde işlediğine göre $N$. S. and Others kararının ATM'ye aktarılması bir zaman meselesi olsa gerektir (Bu yönde bkz. Janssens, 2013: 207, 207-8 ve 229; Montaldo, 2016: 980 ve Van den Sanden, 2012: 170).

İkinci perdede, ABAD, 2014 yılında Genel Kurul olarak AB'nin AİHS'ye katılımı taslak anlaşmasının kurucu antlaşmalar ile uyumu ile ilgili 2/13 sayılı Görüşünü, olumsuz olarak, vermiştir. Bu Görüş ile bir yandan karşılıklı güven ilkesi (bir tür) anayasal ilke statüsüne yükseltilmiş ( $\mathrm{Bu}$ yönde bkz. HerlinKarnell, 2014: 41-43; Gill-Pedro ve Groussot, 2017: 265-66; Lenaerts, 2017: 806, 813 ve 838; Mitsilegas, 2016: 160 ve Prechal, 2017: 76 ve 92), diğer yandan bu ilke ile temel hakların korunması arasındaki ilişkiye ABAD'ın ve AİHM'nin yaklaşım fark1 açık edilmiştir. Birincisi (Accession of the European Union to the European Convention for the Protection of Human Rights and Fundamental Freedoms, O-2/13, 2014, para. 191-192):

“... üye devletler arasındaki karşılıklı güven ilkesi, iç sınırları olmayan bir alanın yaratılmasına ve sürdürülmesine imkan tanıdığı için $\mathrm{AB}$ hukukunda asli önem taşır. Bu ilke, özellikle özgürlük, güvenlik ve adalet alanı yönünden her bir devletin, istisnai durumlar saklı kalmak kaydıyla, diğer tüm üye devletlerin $\mathrm{AB}$ hukukuna ve özellikle $\mathrm{AB}$ hukukunun tanıdığı temel haklara uyduğunu addetmelerini gerektirir. ...

Öyleyse $A B$ hukuku uyarınca üye devletlerin $A B$ hukukunu uygularken diğer üye devletlerin temel haklara riayet ettiğini varsaymaları gerekir, böylece onlar, diğer üye devletlerden $\mathrm{AB}$ hukukunun öngördüğünden daha yüksek düzeyde ulusal temel hak koruması talep edemeyeceği gibi, istisnai durumlar saklı kalmak kaydıyla, diğer üye devletin spesifik bir vakada $\mathrm{AB}$ hukukunun güvence altına aldığ 1 temel haklara gerçekten riayet edip etmediğini kontrol de edemez."

İkincisi, AİHS, AB üyesi devletler arasındaki ilişsiler $\mathrm{AB}$ hukukuna tabiyken " $\mathrm{AB}$ hukuku üye devletler arasında karşılıklı güven yükümlülüğü vazetmiş olmakla birlikte, bir üye devletin bir başka üye devletin temel haklara uyup uymadığını kontrol etmesini gerektirirse [AİHS'ye katılım], AB'nin temelini oluşturan dengeyi bozabilir ve $\mathrm{AB}$ hukukunun özerkliğini 
zayiflatabilir" (Accession of the European Union to the European Convention for the Protection of Human Rights and Fundamental Freedoms, O-2/13, 2014, para. 194). İki alt paragrafta daha net ortaya konacak olmakla birlikte, özetle, çıkış noktası olarak ABAD karşılıklı güven ilkesini, AİHM ise temel hakların korunmasını almaktadır.

Üçüncü perdede, 2016 yılında ABAD ATM ile ilgili ve AİHM ATM gibi karşılıklı güven ilkesi temelinde işleyen medeni ve ticari konularda yabancı kararların tanınması ve tenfizi hakkındaki 44/2001 sayılı Tüzük ([2001] OJ L 12/1) ile ilgili karar almıştır. ABAD, 5 Nisan 2016 tarihinde, beş paragraf önce ele aldığımız, Aranyosi and Căldăraru kararı ile özetle şu hükme varmıştır: ABTHŞ md. 4 gereği bir üye devlet, bir kişiyi ülkesinde sistemik eksiklikler olan ve o kişinin kötü muameleye tâbi tutulmaya yönelik gerçek bir risk ile karşı karşıya kalacağına inanmak için esaslı sebepler bulunan bir başka üye devlete teslim edemez (Pál Aranyosi and Robert Căldăraru v Generalstaatsanwaltschaft Bremen, Joined cases C-404/15 and 659/15 PPU, 2016, para. 94). ABAD, böylece bu kez ATM yönünden karş1lıklı güven ilkesine temel hakların korunması kaynaklı ilk sınırı çizmiştir ( $\mathrm{Bu}$ yönde bkz. Willems, 2016: 225). AİHM ise, 23 Mayıs 2016 tarihinde aldığ1 Avotiņš v. Latvia kararı ile $\mathrm{AB}$ hukukundaki karşılıklı güven ilkesi temelli gelişmelere cevap verme firsatı yakalamıştır. AİHM, "temel haklar ve karşılıklı güven ilkesi” ile ilgili ABAD kararlarını da not düştüğü kararında, öncelikle Michaud kararı ile geliştirdiği haliyle Bosphorus testinin ve dahası somut olay yönünden de denk koruma karinesinin uygulanabilir olduğunu belirtmiştir (Avotiňš v. Latvia, No. 17502/07, 2016, para. 46-49, 101-104 ve 105-112). AİHM, sonrasında, bu karine çürütülebilir mi, başka bir deyişle somut olay yönünden AİHS haklarının korunması açıkça yetersiz mi incelemesine geçmiştir. AİHM'ye göre (Avotiņš v. Latvia, No. 17502/07, 2016, para. 113-114, 116):

“... Mahkeme, ABİHA’nın 67. maddesinde anılan özgürlük, güvenlik ve adalet alanının inşası için karşılıklı tanıma mekanizmasının ve bunun gerektirdiği karşılıklı güvenin önemini hatırında tutmaktadır. ... Bununla birlikte, bu alanı yaratmak için kullanılan yöntemler, aslen ABİH'nın 67(1). maddesi ile de teyit edildiği gibi, bu mekanizmaların etkilediği kişilerin temel haklarını ihlal etmemelidir. Buna karşın, açıktır ki, kullanılan yöntemlerden bir kısmının güttüğü etkililik amacı, temel haklara riayet denetiminin sıkıca düzenlenmiş ve hatta sınırlanmış olması ile sonuçlanmaktadır. [ABAD temel hak denetimini istisnai durumlara hasretmişse de] ... bu, uygulamada, Sözleşme'nin vazettiği gerekliliğe gönderilen devlet mahkemesinin, temel hakların korunmasının açıkça yetersiz olmadığından emin olmak adına, en azından, köken devletteki temel hak ihlaline yönelik her türlü ciddi iddianın ağırlık derecesi ile orantılı bir denetim yürütmeye yetkili olması gerekliliğine- aykırı düşebilir. ... 
... Mahkeme, karşılıklı tanıma ilkesinin temel hakların zararına olarak otomatik ve mekanik olarak uygulanmadığını doğrulamalıdır. ... $\mathrm{O}$ halde, $[\mathrm{AB}$ üyesi devlet mahkemesi], $\mathrm{AB}$ hukukunun getirdiği karşılıklı tanıma mekanizmasını uygulamaya çağrıldığında, Sözleşme haklarının korunması açıkça yetersiz olarak addedilemediğinde, bu mekanizmaya tam etki vermelidir. Buna karşın, bu mahkemeler, önlerinde Sözleşme haklarının korunmasının açıkça yetersiz olduğu yönünde ciddi ve destekli bir şikâyet ileri sürüldüğünde ve $[\mathrm{AB}]$ hukuku bu duruma hukuki çare getiremediğinde, salt $\mathrm{AB}$ hukukunu uyguladıkları gerekçesiyle bu şikâyeti incelemekten kaçınamaz."

Üçüncü perde sonunda, denilebilir ki hem ABAD hem de AİHM, karşılıklı güven ilkesi ile temel hakların korunması arasındaki denge noktası konusunda diğer mahkemeyi kendine doğru çekmeye çalışmaktadır. Birincisi (Bu yönde bkz. Gragl, 2017: 565; Marguery, 2016: 944-45 ve 963 ve Mitsilegas, 2016: 162), ABAD açısından özellikle 2/13 sayılı Görüşü ve bunu takip eden Aranyosi and Căldăraru kararı ile ortaya konulduğu üzere karşılıklı güven ilkesi esastır, dolayısıyla bir üye devlet spesifik bir vakada bir başka üye devletin temel haklara gerçekten riayet edip etmediğini kural olarak kontrol etmemelidir (Bu yönde bkz. Eeckhout, 2015: 969; Larsen, 2015: 456; Lenaerts, 2017: 821-22 ve Willems, 2016: 227). AİHM açısından özellikle Avotiņš v. Latvia kararı ile belirtildiği üzere temel hakların korunması esastır, öyleyse bir devlet spesifik bir vakada bir başka devletin temel haklara gerçekten riayet edip etmediğini kural olarak kontrol edebilmelidir. İkincisi (Bu yönde bkz. Brouwer, 2016: 917-18; Eeckhout, 2015: 968; Mitsilegas, 2016: 161 ve Reinbacher ve Wendel, 2016: 710. Krş. Gáspár-Szilágyi, 2016: 217-18 ve Montaldo, 2016: 985-88), ABAD açısından ancak sistemik eksiklikler varsa ve bireysel durum nazarında temel hak ihlaline yönelik gerçek bir risk söz konusuysa karş1lıklı güven ilkesi bir kenara bırakılabilir (Örneğin bkz. N. S. v Secretary of State for the Home Department and M. E. and Others $v$ Refugee Applications Commissioner and Minister for Justice, Equality and Law Reform, Joined cases C-411/10 and 493/10, 2011, para. 106). Oysa AİHM açısından sistemik eksiklik olsa da olmasa da bir kişinin bireysel durumu temel hak ihlaline yönelik gerçek bir riske işaret ediyorsa karşılıklı güven ilkesi bir kenara bırakılmalıdır (Örneğin bkz. Tarakhel v. Switzerland, No. 29217/12, 2014, para. 93).

Dördüncü perdede, ABAD, 2017 yılında Dublin III Tüzüğü ([2013] OJ L 180/31) ile ilgili olan C. K. and Others kararını almıştır. ABAD, bu karar ile N. S. and Others kararından ayrılarak- sistemik eksiklik koşulunu, en azından Dublin III Tüzüğü bağlamında, bir ön koşul olmaktan çıkarmıştır. Somut uyuşmazlıkta (C. K. and Others v Republika Slovenija, Case C-578/16 PPU, 2017: para. 71, 73-74, 90 ve 95), ciddi bir akli veya fiziksel hastalığı olan bir kişi, Dublin III Tüzüğü çerçevesinde Slovenya'dan Hırvatistan'a gönderilmek istenmektedir. Hırvatistan, sağlık hizmetlerine erişim bakımından, iltica 
prosedüründe ve sığınmacıları karşılama koşullarında herhangi bir sistemik eksiklik bulundurmamaktadır. Hal böyle olsa bile "sağlık durumu özellikle ciddi olan bir sığınmacının transferinin, kendiliğinden, o kişi açısından, [ABTHŞ’nin] 4. maddesi anlamında insanlık dışı veya alçaltıcı muameleye yönelik gerçek bir risk oluşturabileceği göz ardı edilemez". "Özellikle ciddi bir akli veya fiziki hastalığı bulunan bir sığınmacının transferi, sağlık durumunda kayda değer ve kalıcı bir kötüleşmeye yönelik gerçek ve kanıtlanmış bir riskle sonuçlanacaksa" o transfer kötü muamele oluşturuyor demektir. Böyle bir durumda ilgili sığınmacının transferi, en azından o kişinin sağlık durumu tekrar el verene kadar, durdurulmalıdır. Bu yorum, "karşılıklı güven ilkesi ile tam olarak uyum içindedir, çünkü temel hakların her bir üye devlette saygı gördügü varsayımının varlığını etkilemekten çok, üye devletlerin [istisnai durumları] gereği gibi göz önüne almasını sağlamaktadır".

C. $K$. and Others kararı, ABAD ile AİHM arasındaki diyalogun son perdesi olarak, iki çıkarımda bulunmaya izin verir niteliktedir. Birincisi, ABAD, karşılıklı güven ilkesi karşısında temel hakların korunması ile ilgili iki aşamalı (sistemik eksiklik + bireysel durum) testini tek aşamalı (bireysel durum) teste çevirmiş izlenimi vermektedir. Hatta ABAD hâkimi de olan Prechal'e göre $C$. $K$. and Others kararına gelmeden, Aranyosi and Căldăraru kararı bile "“sistemik eksiklikler'in temel hakların korunmasının denkliği karinesini çürütmek açısından vazgeçilmez bir koşul olmadığını göstermektedir” (Prechal, 2017: 88). Eğer hal böyleyse bu alandaki yaklaşımları yönünden ABAD AİHM'nin çizgisini benimsemiştir demektir (Bu yönde bkz. Lenaerts, 2017: 834; Reinbacher ve Wendel, 2016: 711; Xanthopoulou, 2018: 498). İkincisi, ABAD, temel hakların korunması ile ilgili halleri, her ne kadar karşılıklı güven ilkesi açısından istisnai durum olarak görüyor olsa da, bunu ciddiye aldığını ve üye devletlerin de bu istisnai durumları gereği gibi dikkate alması gerektiğini belirtmiştir. $\mathrm{Bu}$ tespit de, bu alandaki yaklaşımları yönünden ABAD'ın AİHM'nin çizgisini tam olarak benimsemese de, ona doğru kaydığının bir göstergesi olarak okunabilir. Zira çıkış noktaları farklı da olsa, her iki mahkeme de, özünde, temel hakların korunmasının ciddiyetle ele alınması gerektiğini söylemektedir. Bu yönden, aynı zamanda ABAD Başkanı da olan Lenaerts'e göre: "[AİHM'nin] Avotiņ̌̌ v. Latvia kararının altında yatan rasyonel, ABAD'ın N. S. and Others, C. K. and Others ve Aranyosi and Căldăraru kararları ile kabul ettiği karşılıklı güven ilkesinin yorumu ile uyumludur" (Lenaerts, 2017: 827-28). Son olarak, nasıl ki Dublin II Tüzüğü ile ilgili $N$. S. and Others kararının ATM ile ilgili Aranyosi and Căldăraru kararı ile takip edilmesi bir an meselesi olmuştur, Dublin III Tüzüğü ile ilgili $C$. K. and Others kararının da ATM ile ilgili bir başka kararda takip edilmesi zaman işidir denilebilir $(\mathrm{Bu}$ yönde bkz. Xanthopoulou, 2018: 496). Nitekim ABAD, 25 Temmuz 2018 tarihli $M L$ kararı ile, bu kez ATM yönünden, iki aşamalı testi tek aşamalı teste indirmemekle birlikte (ML, Case C-220/18 PPU, 2018, para. 60-66), temel 
hakların korunması ile ilgili halleri ciddiye aldığını gösterme firsatı yakalamıştır (ML, Case C-220/18 PPU, 2018, para. 65). Öyleyse, ABAD'ın bu son dönemki kararları, 2/13 sayılı Görüşü ile ortaya koyduğu karş1lıklı güven ilkesini temel hakların korunması karşısında önceleyen yaklaşımını, belki de AİHM'nin herhangi bir somut olay yönünden Bosphorus testindeki denk koruma karinesini çürütülebilir bulma kaygısı altında da kalarak, yumuşatma gayreti olarak değerlendirilebilir.

Aranyosi and Căldăraru kararının bir sonucu, yukarıda görüldüğü üzere, ABAD ile AİHM arasındaki diyalog temelindeki denge noktası tartışmalarıysa diğer sonucu, ABAD ile ulusal mahkemeler arasındaki diyalog temelinde karşılıklı güven ilkesi ile temel haklar arasındaki ilişkiye yönelik ABAD önüne taşınan yeni sorulardır. İlk olarak, 25 Temmuz 2018 tarihli $M L$ kararı, tıpkı Aranyosi and Căldăraru kararı gibi, hapishane koşulları ile kötü muamele yasağı ilişkisi ile ilgili olup bu kararın üstüne yeni tuğlalar eklemiştir. Birincisi, herhangi bir etkili başvuru yolu, tek başına, kötü muameleye yönelik gerçek bir risk oluşumunun önüne geçecek midir? Örneğin bir üye devlet, hapisteki kişilere hapishane koşullarının temel haklar 1şı̆̆ında hukuka uygun olmadığı itirazını mahkeme önünde yapma imkânı getirmiş olabilir, ancak "böyle bir hukuki çare, [ABTHŞ'nin] 47. maddesi anlamında etkili başvuru yolu oluştursa bile, kendiliğinden, [ilgili kişinin kötü muameleye] maruz kalacağı gerçek riskini ortadan kaldırmak için yeterli addedilemez" (ML, Case C-220/18 PPU, para. 72-73). İkincisi, yürüten yargısal makam, yalnızca bir kişinin ilk planda tutulması planlanan hapishanedeki koşulları mı, yoksa daha sonraki aşamalarda tutulabileceği hapishanelerdeki koşulları da mı göz önüne almalıdır? ATM sisteminin temel aldığı "üye devletler arasında var olması gereken karşılıklı güven ışığında" yürüten yargısal makamlar yalnızca, geçici olanlar dâhil, ilgili kişinin tutulması planlanan hapishane koşullarını incelemelidir $(M L$, Case C220/18 PPU, para. 87. Krş. Hirsi Jamaa and Others v. Italy, No. 27765/09, 2012, para. 146-158), ayrıca hapishanenin geçici niteliği, tek başına, kötü muameleye yönelik gerçek riski bertaraf etmez ( $M L$, Case C-220/18 PPU, para. 100). Üçüncüsü, çıkaran üye devlet ilgili kişinin hangi hapishanede tutulursa tutulsun kötü muameleye maruz kalmayacağı yönünde teminat verirse bunun değeri ne olacaktır? Eğer böyle bir teminat "çıkaran yargısal makam tarafından veriliyor veya en azından tasdik ediliyorsa" yürüten yargısal makam, ATM sisteminin temel aldığı "üye devletler arasında var olması gereken karşılıklı güven ışığında", en azından belirli bir hapishanedeki koşulların kötü muamele yasağını ihlal ettiğine dair "spesifik göstergelerin yokluğunda" bu teminatın doğruluğuna güvenmelidir ( $M L$, Case C-220/18 PPU, para. 111-112. Krş. Othman (Abu Qatada) v. United Kingdom, No. 8139/09, 2012, para. 189).

İkinci olarak, ABAD, Büyük Daire olarak yine 25 Temmuz 2018 tarihli LM kararı ile, bu kez, adil yargılanma hakkı ve ABA'nın 7. maddesi prosedürü ile 
ilgili cevaplar geliştirmiştir (Bu prosedür yönünden diğerleri arasından (bkz. Reçber ve Aydın, 2004: 89-115; Yumak, 2017: 199-218). Birincisi, karş1lıklı güven ilkesi karşısında yalnızca kötü muamele yasağı mı koruma altındadır, yoksa diğer temel haklar, örneğin adil yargılanma hakkı da, koruma altında mıdır? Yürüten yargısal makam, eğer ilgili kişi "çıkaran yargısal makama teslim edilirse bağımsız mahkeme temel hakkının, dolayısıyla adil yargılanma temel hakkının özünün ihlaline maruz kalacaksa", istisnai olarak, ATM'ye etki vermekten kaçınabilir ( $L M$, Case C-216/18 PPU, 2018, para. 59. Krş. Bader and Kanbor v. Sweden, No. 13284/04, 2005, para. 41-42 (AİHS md. 2); Othman (Abu Qatada) v. United Kingdom, No. 8139/09, 2012, para. 233 (AİHS md. 5) ve Al-Nashif v. Bulgaria, No. 50963/99, 2002, para. 114 (AİHS md. 8)). İkincisi, peki ABA'nın 7. maddesi prosedürü ile karş1lıklı güven ilkesini temel alan ATM arasındaki ilişki nasıl olmalıdır? Bir taraftan, yürüten yargısal makam, bir üye devlet açısından ABA'nın 7. maddesi uyarınca 2002/584 sayılı Çerçeve Karar askıya alınırsa o devletin çıkardığı ATM'yi uygulamayı otomatik olarak geri çevirmekle yükümlüdür ( $L M$, Case C-216/18 PPU, 2018, para. 72). Diğer taraftan, yürüten yargisal makam, örneğin Komisyon gerekçeli görüş sunarak süreci başlatmış olsa bile bir üye devlet açısından ABA'nın 7. maddesi çerçevesinde henüz bir karar alınmadığında adil yargılanma hakkının özünün ihlaline yönelik gerçek risk olup olmadığına somut olay bazında karar vermelidir ( $L M$, Case C-216/18 PPU, 2018, para. 73). LM kararı önem taşımaktadır, çünkü Polonya ABA'nın 7. maddesi prosedürü yönünden tekil örnek değildir, başta Macaristan olmak üzere ileride örnekler çoğalabilir (Avrupa Parlamentosu Basın Açıklaması, 2018).

Ayrıca $L M$ kararı, örtülü olarak, bir başka sorunun yanıtına daha 1şık tutuyor olabilir: Teslimi istenen kişi, yalnızca gelecekte uğrayacağı temel hak ihlaline karşı mı, yoksa geçmişte uğradığ1 temel hak ihlaline karşı da mı itirazda bulunabilir? Yukarıda ele alındığı üzere, HS Sharpston Radu davasındaki Görüşü ile bu konuda pozitif yönde fikir beyan etmiştir (Proceedings relating to the execution of European arrest warrants issued agains Ciprian Vasile Radu, Case C-396/11, 2012, pt. 97), ancak ABAD'ın henüz bununla ilgili bir karar1 yoktur. Aslında $L M$ kararı da bu sorunun yanıtı ile ilgilenmemektedir, ancak karar içindeki bir paragraf, belki de, cevaba yönelik ipucunu içerisinde barındırıyor olabilir: “...yalnızca [ATM'yi] uygulama kararı değil, aynı zamanda [ATM'yi] çıkarma kararı da, etkili yargısal korumada içkin gereklilikleri karşılayan yargısal makamlar tarafından alınmalıdır" ( $L M$, Case C-216/18 PPU, 2018, para. 56). ABAD'ın bu tespitindeki yaklaşımı, eğer ileride başka bağlamda önüne getirilirse, teslimi istenen kişiye geçmişte uğradığı temel hak ihlaline karşı da itirazda bulunma imkânı tanıyabileceğine yönelik, zayıf da olsa, bir işaret olarak okunabilir. Bununla birlikte, daha kuvvetli bir gösterge olarak, böyle bir yaklaşımın AİHM kararları ile de 
paralellik taşıyacağı belirtilebilir (Örneğin bkz. Bader and Kanbor v. Sweden, No. 13284/04, 2005, para. 42).

Üçüncü olarak, ABAD, 19 Eylül 2018 tarihli $R O$ kararı ile ATM'yi ABA'nın 50. maddesi prosedürü -Brexit- 1şı̆̆ında ele almışıır (Bu prosedür yönünden diğerleri arasından (bkz. Bilgin, 2014: 205-43; Hillion, 2017: 21533). $R O$ kararında şu soru yanıtlanmıştır (Minister for Justice and Equality $v$ RO, Case C-327/18 PPU, 2018, para. 33, 43, 45, 48-49, 52 ve 61): Acaba, yürüten yargısal makam, ABA'nın 50. maddesi uyarınca çekilme niyetini $\mathrm{AB}$ Zirvesine bildiren bir üye devletin çıkardığı ATM'yi uygulamayı geri çevirmeli veya çekilme anlaşması tamamlanana kadar bekletmeli midir? Zira başvurucunun argümanına göre karşlıklı güven ilkesi "bu bildirim ile birlikte telafi edilemez biçimde sarsılmıştır", dolayısıyla ATM geri çevrilmelidir. ABAD'a göre ise, birincisi, böyle bir bildirim ilgili üye devlette $A B$ hukukunun uygulanmasının önüne geçmez, o halde "o devletin [AB'den] gerçek çekilme anına kadar ... karşıllklı güven ilkesi de tam gücünü ve etkisini sürdürür", başka bir ifadeyle, böyle bir bildirim, kendiliğinden, karşıllklı güven ilkesi açısından istisnai durum oluşturmaz. Bununla birlikte, yürüten yargısal makam, çıkaran üye devletin $\mathrm{AB}$ 'den çekilmesini takiben ilgili kişinin temel haklarından mahrum kalma riski altında olduğuna inanmak için sağlam sebepler olup olmadığını incelemekle yükümlüdür. Bununla birlikte, burada çıkaran üye devlet, yani Birleşik Krallık, AİHS'nin tarafidır ve AB'den çekilse bile orada kalacaktır, dolayısıyla örneğin kötü muamele yasağı ile ilgili yükümlülüğü sürecektir ve varsayım olarak bu yükümlülüğe riayet edecektir. $O$ halde, yürüten üye devlet, yalnızca bunun aksine somut delil mevcutsa ATM'yi uygulamayı geri çevirebilir.

\section{Sonuç}

ABAD içtihat hukuku incelendiğinde, karşılıklı güven ilkesinin, ATM örneğinin gösterdiği üzere, ilk y1llarda temel hakların gereği gibi korunmadığ 1 iddialarından hiçbir biçimde etkilenmeyecek bir mutlak karineden, başta bu ilkenin özellikle de ABAD ile AİHM arasındaki ilişkiler temelinde üstünde oluşan baskıyı kırabilmek veya en azından hafifletebilmek nedeniyle, temel hakların korunması ile arasında makul denge aranan bir çürütülebilir karineye dönüştüğü görülmektedir.

Bununla birlikte, bu dönüşümün tamamlandığından bahsetmek pek mümkün gözükmemektedir. Bir taraftan, ABAD ile AİHM arasindaki diyalog, bir tür bilek güreşine de dönüşmüş vaziyette olarak, karşılıklı güven ilkesi ile temel hakların korunması arasındaki makul denge noktasl konusunda sürecek gözükmektedir. Özellikle de, ABAD'ın bu konuda izlediği iki aşamalı (sistemik eksiklik + bireysel durum) testi tek aşamalı (bireysel durum) test ile, sözde olmasa bile öz itibariyle, her hal ve şartta değiştirip değiştirmeyeceği ve 
karş1lıklı güven ilkesi çıkış noktası kalsa bile temel hakların korunmasının ciddiyetle ele alınması gerekliliğini her firsatta dile getirip getirmeyeceği, makul denge noktası meselesi ile ilgili öne çıkan hususlar olarak belirtilebilir. AİHM, 6 Mart 2018 tarihli olan ve çocuk kaçırma alanı ile ilgili bulunan güncel bir kararında yine -Avotiņš v. Latvia kararının 116. paragrafında belirttiği üzere- "karşılıklı tanıma ilkesinin otomatik ve mekanik biçimde uygulanmadığını doğrulamalıdır" tespitine yer vermektedir (Royer v. Hungary, No. 9114/16, 2018, para. 50). ABAD, AİHM'nin bu sağlam duruşu sürdüğü müddetçe, bu mahkemenin temel haklar söz konusu olduğundaki çekim kuvveti de hesaba katıldığında, AİHM'nin çizgisine doğru seyredecektir denilebilir.

Diğer taraftan, ABAD ile ulusal mahkemeler arasındaki diyalog, karşılıklı güven ilkesi ile temel hakların korunması arasındaki ilişkinin tüm parametrelerinin ortaya konulabilmesi adına, sürecek gözükmektedir. Ulusal mahkemeler, Aranyosi and Căldăraru kararını takiben, şimdiye kadar hapishane koşulları, ABA'nın 7. maddesi prosedürü ve 50. maddesi prosedürü ile ilgili olarak ön karar prosedürü aracılığıyla ABAD'a yeni sorular yöneltmiştir. Bugüne bakıldığında, örneğin hapishane koşulları ile ilgili olan birtakım başka soruların da ABAD önünde derdest beklediği görülmektedir (Criminal proceedings against Dumitru-Tudor Dorobantu, Case C-128/18, 2018). Bu da, ABAD'ın her bir yanıtının yeni sorulara kapı açtığını, dolayısıyla $\mathrm{ABAD}$ ile ulusal mahkemeler arasındaki diyalogun karşılıklı güven ilkesi ile temel hakların korunması arasındaki ilişkinin tüm parametreleri ortaya çıkana kadar süreceğine işaret etmektedir. 


\section{Kaynakça:}

Al-Nashif v. Bulgaria, no. 50963/99, 20 September 2002.

Arsava, F. A. (2017) “AB Temel Haklarının Üye Devletler Arasında Korunması", Türkiye Adalet Akademisi Dergisi 8(31): 1-25.

Avotiņš v. Latvia [GC], no. 17502/07, 23 May 2016.

Avrupa Birliği (1992), Treaty on European Union [1992] OJ C 191/1.

Avrupa Birliği (1997), Treaty on European Union (consolidated version 1997) [1997] OJ C 340/145.

Avrupa Birliği (2001), Council Regulation (EC) No 44/2001 of 22 December 2000 on jurisdiction and the recognition and enforcement of judgments in civil and commercial matters [2001] OJ L 12/1.

Avrupa Birliği (2002), Council Framework Decision 2002/584/JHA of 13 June 2002 on the European arrest warrant and the surrender procedures between Member States - Statements made by certain Member States on the adoption of the Framework Decision [2002] OJ L 190/1.

Avrupa Birliği (2003), Council Regulation (EC) No 343/2003 of 18 February 2003 establishing the criteria and mechanisms for determining the Member State responsible for examining an asylum application lodged in one of the Member States by a third-country national [2003] OJ L 50/1.

Avrupa Birliği (2007), Consolidated version of the Treaty on the Functioning of the European Union [2012] OJ C 326/47.

Avrupa Birliği (2007), Consolidated version of the Treaty on the Functioning of the European Union [2012] OJ C 326/47.

Avrupa Birliği (2009), Council Framework Decision 2009/299/JHA of 26 February 2009 amending Framework Decisions 2002/584/JHA, 2005/214/JHA, 2006/783/JHA, 2008/909/JHA and 2008/947/JHA, thereby enhancing the procedural rights of persons and fostering the application of the principle of mutual recognition to decisions rendered in the absence of the person concerned at the trial [2009] OJ L 81/24.

Avrupa Birliği (2013), Regulation (EU) No 604/2013 of the European Parliament and of the Council of 26 June 2013 establishing the criteria and mechanisms for determining the Member State responsible for examining an application for international protection lodged in one of the Member States by a third-country national or a stateless person [2013] OJ L 180/31.

Avrupa Birliği Zirvesi (1999), Presidency Conclusions of the Tampere European Council, 15-16 October 1999, Bulletin of the European Union 10/1999. 
Avrupa Parlamentosu Basın Açıklaması (2018), $<$ http://www.europarl.europa.eu/news/en/pressroom/20180906IPR12104/rule-of-law-in-hungary-parliament-calls-on-theeu-to-act>, (12/9/2018).

Bader and Kanbor v. Sweden, no. 13284/04, 8 November 2005.

Baykal, S. (2010) “Temel Haklar”, B. Akçay ve G. Bayraktaroğlu Özçelik (ed.), Lizbon Antlaşması Sonrası Avrupa Birliği: Serbest Dolaşım ve Politikalar, (Ankara:Seçkin Yayıncılık), ss. 371-399.

Baykal, S. ve Göçmen, İ. (2016) Avrupa Birliği Kurumsal Hukuku, (Ankara: Seçkin Yayıncılık).

Bilgin, A. A. (2014) "Avrupa Birliğinden Çekilme Hakkı: Sonun Başlangıcı mı?”, Gazi Üniversitesi Hukuk Fakültesi Dergisi XVIII(3-4): 205-43.

Brouwer, E. (2016) "Mutual Trust and Human Rights in the AFSJ: In Search of Guidelines for National Courts", Europan Papers 1(3): 893-920.

BVerfG, Order of the Second Senate of 18 July 2005 - 2 BvR 2236/04.

Criminal proceedings against Dumitru-Tudor Dorobantu, Case C-128/18.

Eeckhout, P. (2015) "Opinion 2/13 on EU Accession to the ECHR and Judicial Dialogue: Autonomy or Autarky", Fordham International Law Journal 38(4): 955.

Erdem, M. R. (2004) Avrupa Birliği Hukuku'nun Üye Devletlerin Ceza ve Ceza Muhakemesi Hukukuna Etkileri, (Ankara: Seçkin Yayıncılık).

Fabbrini, F. ve Larik, J. (2016) "The Past, Present and Future of the Relation between the European Court of Justice and the European Court of Human Rights", Yearbook of European Law 35(1): 145-79.

Gáspár-Szilágyi, S. (2016) "Joined Cases Aranyosi and Căldăraru: Converging Human Rights Standards, Mutual Trust and a New Ground for Postponing a European Arrest Warrant”, European Journal of Crime, Criminal Law and Criminal Justice 24(2-3): 197-219.

Gill-Pedro, E. ve Groussot, X. (2017) “The Duty of Mutual Trust in EU Law and the Duty to Secure Human Rights: Can the EU's Accession to the ECHR Ease the Tension?", Nordic Journal of Human Rights 35(3): 258-74.

Göçmen, İ. (2013) "The Contributions of The Court of Justice of the European Union to Judicial Cooperation in Criminal Matters with a Specific Focus on The Protection of Fundamental Rights", Ankara Avrupa Çalışmaları Dergisi 12(1): 129-70. 
Gragl, P. (2017) “An Olive Branch from Strasbourg? Interpreting the European Court of Human Rights' Resurrection of Bosphorus and Reaction to Opinion 2/13 in the Avotiňs Case: ECtHR 23 May 2016, Case No. 17502/07, Avotiņš v Latvia”, European Constitutional Law Review 13(3): 551-67.

Gündoğdu, M. (2018) Avrupa Birliği Insan Hakları Rejimi Işı̆̆ında Avrupa Tutuklama Müzekkeresi, (Ankara: Adalet Yayınevi).

Herlin-Karnell, E. (2014) "Constitutional Principles in the Area of Freedom, Security and Justice", D. A. Arcarazo ve C. C. Murphy (ed.) EU Security and Justice Law: After Lisbon and Stockholm, (Oxford: Hart Publishing), s. 38-53.

Hillion, C. (2017) "This Way, Please! A Legal Appraisal of the EU Withdrawal Clause", C. Closa (ed.) Secession from a Member State and Withdrawal from the European Union: Troubled Membership, (Cambridge: Cambridge University Press), s. 215-33.

Hirsi Jamaa and Others v. Italy [GC], No. 27765/09, 23 February 2012.

Janssens, C. (2013) The Principle of Mutual Recognition in EU Law, (Oxford: Oxford University Press).

Judgement of 10 November 2016, Openbaar Ministerie v Krzysztof Marek Poltorak, Case C-452/16 PPU, ECLI:EU:C:2016:858.

Judgement of 10 November 2016, Openbaar Ministerie v Ruslanas Kovalkovas, Case C-477/16 PPU, ECLI:EU:C:2016:861.

Judgement of 16 February 2017, C. K. and Others v Republika Slovenija, Case C-578/16 PPU, ECLI:EU:C:2017:127.

Judgement of 16 July 2015, Minister for Justice and Equality v Francis Lanigan, Case C-237/15 PPU, ECLI:EU:C:2015:474.

Judgement of 16 November 2010, Gaetano Mantello, Case C-261/09, ECLI:EU:C:2010:683.

Judgement of 17 July 2008, Proceedings concerning the execution of a European arrest warrant issued against Szymon Kozłowski, Case C-66/08, ECLI:EU:C:2008:437.

Judgement of 19 September 2018, Minister for Justice and Equality $v$ RO, Case C-327/18 PPU, ECLI:EU:C:2018:733.

Judgement of 21 December 2011, N. S. v Secretary of State for the Home Department and M. E. and Others $v$ Refugee Applications Commissioner and Minister for Justice, Equality and Law Reform, Joined cases C-411/10 and C-493/10, ECLI:EU:C:2011:865.

Judgement of 21 October 2010, I.B., Case C-306/09, ECLI:EU:C:2010:626. 
Judgement of 24 May 2016, Openbaar Ministerie v Pawet Dworzecki, Case C108/16 PPU, ECLI:EU:C:2016:346.

Judgement of 25 January 2017, Minister for Justice and Equality v Tomas Vilkas, Case C-640/15, ECLI:EU:C:2017:39.

Judgement of 25 July 2018, $A Y$, Case C-268/17, ECLI:EU:C:2018:602.

Judgement of 25 July 2018, LM, Case C-216/18 PPU, ECLI:EU:C:2018:586.

Judgement of 25 July 2018, ML, Case C-220/18 PPU, ECLI:EU:C:2018:589.

Judgement of 26 February 1986, M. H. Marshall $v$ Southampton and South-

West Hampshire Area Health Authority (Teaching), Case 152/84. ECLI:EU:C:1986:84.

Judgement of 26 February 2013, Stefano Melloni v Ministerio Fiscal, Case C399/11, ECLI:EU:C:2013:107.

Judgement of 27 May 2019, OG, Joined cases C-508/18 and C-82/19 PPU, ECLI:EU:C:2019:456.

Judgement of 27 May 2019, PF, Case C-509/18, ECLI:EU:C:2019:457.

Judgement of 28 July 2016, JZ v Prokuratura Rejonowa Łódź - Śródmieście, Case C-294/16 PPU, ECLI:EU:C:2016:610.

Judgement of 29 January 2013, Proceedings relating to the execution of European arrest warrants issued agains Ciprian Vasile Radu, Case C396/11, ECLI:EU:C:2013:39.

Judgement of 30 May 2013, Jeremy F. v Premier ministre, Case C-168/13 PPU, ECLI:EU:C:2013:358.

Judgement of 4 December 1974, Yvonne van Duyn v Home Office, Case 41/74. ECLI:EU:C:1974:133.

Judgement of 5 April 2016, Pál Aranyosi and Robert Căldăraru v Generalstaatsanwaltschaft Bremen, Joined Cases C-404/15 and C-659/15 PPU, ECLI:EU:C:2016:198.

Judgement of 5 September 2012, Proceedings concerning the execution of a European arrest warrant issued against João Pedro Lopes Da Silva Jorge, Case C-42/11. ECLI:EU:C:2012:517.

Judgement of 6 October 1982, CILFIT v Ministero della Sanità, Case 283/81, ECLI:EU:C:1982:335.

Keskin Ata, F. (2013) Avrupa Birliği ve Insan Haklarl, (Ankara: Siyasal Kitabevi).

Larsen, L. B. (2015) "Mutual Recognition in Civil Law Cooperation: The Case of Child Abduction - Some General Remarks in the Light of the Jurisprudence of the CJEU (the Brussels II Bis Regulation)", New Journal of European Criminal Law 6(4): 452-56. 
Lenaerts, K. (2017) "La Vie Apres L'avis: Exploring the Principle of Mutual (yet Not Blind) Trust", Common Market Law Review 54(3): 805-40.

M.S.S. v. Belgium and Greece [GC], No. 30696/09, 21 January 2011.

Marguery, T. (2016) "Rebuttal of Mutual Trust and Mutual Recognition in Criminal Matters: Is 'Exceptional' Enough?”, Europan Papers 1(3): 943-63.

Miettinen, S. (2014), Criminal Law and Policy in the European Union, (New York: Routledge).

Mitsilegas, V. (2009) EU Criminal Law, (Oxford: Hart Publishing).

Mitsilegas, V. (2016), "Mutual Recognition, Mutual Trust and Fundamental Rights After Lisbon". V. Mitsilegas, M. Bergström ve T. Konstadinides (ed.) Research Handbook on EU Criminal Law, (Cheltenham: Edward Elgar Publishing), s. 148-67.

Montaldo, S. (2016) “On a Collision Course! Mutual Recognition, Mutual Trust and the Protection of Fundamental Rights in the Recent Case-law of the Court of Justice", Europan Papers 1(3): s. 965-96.

Opinion of 18 December 2014, Accession of the European Union to the European Convention for the Protection of Human Rights and Fundamental Freedoms, O-2/13, ECLI:EU:C:2014:2454.

Opinion of Advocate General delivered on 18 October 2012, Proceedings relating to the execution of European arrest warrants issued agains Ciprian Vasile Radu, Case C-396/11, ECLI:EU:C:2012:648.

Order of 25 September 2015, Openbaar Ministerie $v$ A, Case C-463/15 PPU, ECLI:EU:C:2015:634.

Ostropolski, T. (2015) "The CJEU as a Defender of Mutual Trust", New Journal of European Criminal Law 6(2): s. 166-78.

Othman (Abu Qatada) v. United Kingdom, No. 8139/09, 17 January 2012.

Peers, S. (2012) EU Justice and Home Affairs Law, 3rd Edition, (Oxford, Oxford University Press).

Prechal, S. (2017) "Mutual Trust Before the Court of Justice of the European Union", Europan Papers 2(1): 75-92.

Reçber, K. ve Aydın, Ç. (2004) “Avrupa Birliği’nde Üye Devletler Tarafından İnsan Haklarının İhlal Edilmesi Durumunda Öngörülen Yaptırımlar", Ankara Üniversitesi Hukuk Fakültesi Dergisi 53(1): 89-115.

Reinbacher, T. ve Wendel, M. (2016) "The Bundesverfassungsgericht's European Arrest Warrant II Decision", Maastricht Journal of European and Comparative Law 23(4): 702-13.

Royer v. Hungary, No. 9114/16, 6 March 2018.

Tarakhel v. Switzerland [GC], No. 29217/12, 4 November 2014. 
Van den Sanden, T. (2012) “Joined Cases C-411/10 \& C-493/10, N.S. V. Sec'y of State for the Home Dep't", Columbia Journal of European Law 19: 143.

Willems, A. (2016) "Mutual Trust as a Term of Art in EU Criminal Law: Revealing Its Hybrid Character", European Journal of Legal Studies 9: 211249.

Woods, L. ve Watson, P. (2014) Steiner \& Woods EU Law, 12th Edition, (Oxford, Oxford University Press).

Wouters, J. ve Naert, F. (2004) "Of Arrest Warrants, Terrorist Offences and Extradition Deals: An Appraisal of the EU's Main Criminal Law Measures against Terrorism after '11 September'", Common Market Law Review 41(4): 909-35.

Xanthopoulou, E. (2018) "Mutual Trust and Rights in EU Criminal and Asylum Law: Three Phases of Evolution and the Uncharted Territory beyond Blind Trust", Common Market Law Review 55(2): 489-509.

Yumak, S. (2017) “Avrupa Birliği Temel Değerleri ve Bu Değerlerin Birliğin Geleceği İçin Taşıdığı Önem: Polonya Örneği Üzerinden Bir İnceleme”, Ankara Avrupa Çalışmaları Dergisi 16(2): 199-218. 